\title{
To Michele Minolli
}

\author{
René Kaës*
}

\begin{abstract}
The article presents a brief interview to describe who Maestro Michele Minolli was, as a person and as a therapist, and the contribution he brought to the profession and to the vision of the relationship among human beings.

Key words: Group; couple; I-subject; relationship; intersubjectivity.
\end{abstract}

What were the personal and relational qualities of Michele Minolli which made him a leading theorist and therapist?

First of all, I would like to recall my encounter with Michele Minolli. He invited me to hold a seminar on the psychoanalytic approach to groups in Milan. This seminar took place over several years. His plan was to open a new teaching and research section in this area within SIPRe, alongside and in relation to the existing sections focused on psychotherapy of the couple and child psychotherapy. The new Master's degree in Psicoanalisi della Relazione di Gruppo (Psychoanalysis of the Group Relationship) included methodological, clinical and theoretical courses, but also an experiential part of the group psychoanalytic psychodrama.

Those who took this course and participated in the psychodrama sessions were able to benefit from supervision and follow up meetings on their practice in the psychodrama group. Thus, they were able to set up a research group. Michele and Romina entrusted to me the task of supporting and accompanying this second phase of work.

I very much appreciated the solidity of the institutional framework that

*Professor emeritus of psychology and psychopathology Université Lumière Lyon 2; psychoanalyst; full member of the Société Française de Psychothérapie psychanalytique de groupe (SFPPG); past president of the Centre d'Études Françaises de Formation et de Recherches Psychanalytiques, Groupe, Psychodrame, Institutions (CEFFRAP).

E-mail: rene.kaes@sfr.fr 
made this work possible, and the necessary, opportune support that Michele and Romina guaranteed to the people who were involved in this training course.

Engaging in this activity I was able to appreciate the personal and relational qualities of Michele and the people with whom he collaborated. It was also in this setting that I appreciated his qualities as a therapist, not directly in his relationship with patients, but in what he said about them, in interventions during seminars, or in our private discussions. His whole person testified to his qualities as a clinician and theorist in his relationships with both students and colleagues.

Over the years I came to know him as a committed, reliable and courteous man, courageous in facing up to the illness, and attentive to difficulties in others' lives.

I also came to know him as a man with whom it was a pleasure and a joy to share moments of relaxation, when we went get a stimulation with a coffee or, for him, a cup of barley coffee. Or when, with Romina and Francesco, we went to the Approdo in the evening to savour fish dishes and Vermentino; these were evenings animated by jokes and theoretical debates late into the night and on our way home or to my hotel.

To what extent and in what way has the person and the tought of Michele Minolli changed our way of working with patients and our vision of human beings?

Michele was a generous and demanding relational being: I think that his contribution to the theory of psychoanalysis of the relationship is based on what he was and on what he transmitted. What he called the Io-soggetto (Isubject) is a central concept in his theory of the relational human being. Although we had different ways of expressing this view, we agreed on the basic hypothesis. We formulated it differently: I rather speak about what I call the subject of the unconscious and of a triple structuring of the psyche: intrapsychic, with its formations and its own processes; intersubjective, with its logic, its processes and its formations; transsubjective, with what it specifies.

However, even though on some essential points our debates were converging, on others they diverged: I can still see his smile and his eyes narrowing in when he was underling a point of disagreement.

On the occasion of a book he wrote with Romina Coin (Minolli \& Coin, 2007) we had a stimulating discussion about the fundamental tension he detected in the relationship between the (real) motivation or project, and its realization. He argued that this tension arises from the inevitable gap - for each subject in the couple and for the relationship - between unconscious 
desires and their fulfilment through the couple relationship. In this gap, the game of narcissistic and objectual investments is established. We agreed on this point. But, from my point of view, in that gap the death drive burrows, with its corresponding thrust, antagonistic to the actualization of the self. We did not share the same theories on the death drive issue, nor on the issue of its absence. 'Why - he wondered with Romina - should the Io-soggetto be seized with the desire for what it does not possess? Why is this selfrealisation, this mirage in the desert, located outside itself?'

Michele had a deep understanding of Freudian thought and Freud's disciples thought. He was extraordinarily open to debate, stating his proposals, not as objections that would put an end to the discussion, but as explorations of what for him opened up to the unknown and, therefore, to some uncertainty.

Can Michele Minolli's thinking be considered courageous and innovative? Why?

Yes, he was courageous because in the often cautious panorama of psychoanalysis, he assumed and affirmed his innovative theoretical position while being open to the thinking of other currents of psychoanalysis. His reading of Freud is accurate, and also sensitive to what he considered to be deviations that he questioned.

To give an example, when M. Minolli thinks that Freud based his entire theoretical construction on the concept of repression/repressed, and through this explained psychic functioning, he immediately points out that the result is a personal vision that is too pathological and could be an illicit generalization. He opposes the hypothesis of $\mathrm{H}$. Hartman on the parts of the ego free from conflict and the idea of I. Berenstein (shared by J. Puget), according to which it is appropriate to avoid (in brief) the situation where objects invested during the course of life are only the Ersatz of the original object, and to consider 'multiple beginnings of a subjective series in which every beginning constitutes an origin in itself'. We were by no means of the same opinion on these issues.

What specific contribution did Michele Minolli's thought make to the field of relational psychoanalysis?

Michele wrote about and argued this point himself (Minolli, 2005): the psychoanalytic intervention of couples seems to present aspects that cannot be referred either to the individual or the group. Hence the need to find a specific, more relevant and better adapted paradigm. We agreed that the 
application of the Freudian corpus to new and specific psychic configurations, in our case the couple (and in mine, the group), had helped the evolution of the psychoanalytic theory, which was enriched with respect to the concepts of the Founding Father. 'The application of psychoanalysis to the couple is situated along this line. It is therefore not surprising that some concepts need to be expanded, others emphasized, and others still need to be introduced' (Minolli, 2005). Included in these new concepts was that of the Io-soggetto which Minolli used to express the need for a Referente unitario di esperienza (unitary Referent of experience). He conceived the Io-soggetto as a unitary organization which is not given at birth, but is constituted in the interaction between the organism (newborn baby) and the environment. He referred to the concept of facilitation on which Freud based his initial conception of the ego in Project for a Psychology (1895), and to experimental Infant Research.

Minolli developed a theory of the couple as representative of the specific dual situation - derived from the symmetry of two partners involved in the real objectives that constitute it.

What tasks has Michele Minolli set for future development, research and expansion?

I have some scruples about answering this question. The colleagues Michele Minolli has worked with in recent years are more qualified than me in identifying the areas that may be developed from his work. I would say only two things. First of all, that the plurality of Master's degrees associated with research groups within the framework of SIPRe constitutes a fruitful work setting from which to launch transversal research in a disciplinary field that is sufficiently homogeneous in its theoretical framework of reference; for example, to develop a thought on the complexity of psychic spaces and temporalities in individual psychic development and in the configuration of the emotional bonds of couples, families, groups and institutions.

Perhaps we should focus our attention more on the relationships between practices and theories inspired by heterogeneous references, and which are imported into the main field of reference. How can we think interactionist concepts borrowed from another frame of reference, maintaining at the same time a psychoanalytic frame, based on unconscious psychic reality? How can we imagine interpersonal regulatory or co-regulatory behaviours using psychoanalysis? How can we understand the couple as a functional system and integrate instinct and the unconscious bedrock of desire? These are some of the epistemological issues that would consolidate the field of relationship psychoanalysis. 


\section{REFERENCES}

Freud, S. (1895). Progetto di una psicologia. Torino: Bollati Boringhieri.

Minolli, M. (2005). Psicoanalisi della relazione di coppia. Ricerca psicoanalitica, XVI(2), 219-242.

Minolli, M., Coin, R. (2007). Amarsi, amando. Per una psicoanalisi della relazione di coppia. Roma: Borla.

Conflict of interests: the author declares no potential conflict of interests.

Ethics approval and consent to participate: not required.

Received for publication: 18 November 2020.

Accepted for publication: 10 December 2020.

${ }^{\circ}$ Copyright: the Author(s), 2020

Licensee PAGEPress, Italy

Ricerca Psicoanalitica 2020; XXXI:496

doi:10.4081/rp.2020.496

This article is distributed under the terms of the Creative Commons Attribution

Noncommercial License (by-nc 4.0) which permits any noncommercial use, distribution,

and reproduction in any medium, provided the original author(s) and source are credited. 
